\title{
MANUFACTURE AND PERFORMANCE EVALUATION OF A LOCAL THRESHING AND CLEANING MACHINE SUITS MEDICINAL AND AROMATIC PLANTS
}

\author{
M. M. Badr
}

$\underline{A B S T R A C T}$

Experiments were carried out to manufacture and evaluate the performance of a threshing and cleaning machine suitable for medicinal and aromatic plants (Anise, Fennel and coriander crops).

The performance of the manufactured machine was studied under the following parameters: four different drum speeds, four different concave clearances and four different feed rates. The performance of the manufactured machine was evaluated taking into consideration the following indicators: total seed losses, overall machine efficiency, machine productivity, required power, energy requirements and criterion cost.

The experimental results reveal that total seed losses as well as criterion costs were minimum while overall machine efficiency was maximum under the following conditions:

- Operate the manufactured machine at a drum speed of about 450 rpm for anise and fennel crops, and 400 rpm for coriander crop.

- Operate the manufactured machine at a concave clearance of about $9 \mathrm{~mm}$ for anise and fennel crops, and $10 \mathrm{~mm}$ for coriander crop.

-Adjust the feed rates at 1.25, 1.35 and $1.50 \mathrm{Mg} / \mathrm{h}$ for anise, fennel and coriander crops respectively.

\section{INTRODUCTION}

edicinal and aromatic crops have an important export value in
Egypt. Anise, fennel and coriander are considered to be three of
the most important medicinal and aromatic plants as they participate in the local consumption added to export value and different aspects. The academic and applied researches indicated that total seed losses occurring through different stages of plants production, is a vital problem to be solved. One of these stages is threshing and cleaning.

\section{"Lecturer of Agric. Eng., Fac. of Agric., Zagazig Univ. Egypt.}


Medicinal and aromatic plants are too sensitive to threshing and cleaning operations due to the high percentage of seed losses affecting on the total yield. Threshing and cleaning machine is the successful answer to clean medicinal and aromatic crops. So, such care had to be taken to design, develop and operate the machine under the optimum conditions to minimize both losses and cost. El-Hadad (2000) stated that the threshing efficiency increased with increasing drum speed and decreasing feed rate. The maximum threshing efficiency was $99.76 \%$ at drum speed of $21.25 \mathrm{~m} / \mathrm{s}$ (1400 rpm), and feed rate of $15 \mathrm{~kg} / \mathrm{min}$. The maximum amount of visible grain damage was $0.90 \%$ under these conditions. El-Nono and Mohammed (2000) found that, the machine power requirement was directly proportional to the drum speed, moisture content and grain damage. Studies on the effect of swinging hammer, spike tooth and rasp bar cylinders on threshing effectiveness and damage of wheat revealed that the cylinder speed and concave clearance were found to be important variables in unthreshed grain and damage model. Increase in cylinder speed and decrease in concave clearance decreased the rate of un-threshed grain and increased grain damage and power requirement. They found out that the swinging hammer type cylinder consumed more power than the rasp bar and spike cylinders. Mandouh et al. (2000) stated that threshing effectiveness was found to be affected by the cylinder speed, the concave clearance, feed rate of crops, the number of rows of concave teeth used with spike tooth cylinder, and the type of crop. Simonyan and Oni (2001) reported that there is an increase in threshing efficiency and extractor efficiency with decrease in moisture content. Threshing effectiveness was also found to be affected by the cylinder speed. Badawy (2002) reported that the highest threshing efficiency was $97.17 \%$ at the optimum performance of flax deseeding machine. By increasing the drum speed from 9.28 to $15.33 \mathrm{~m} / \mathrm{s}$ the capacity increased from 1800 to $2400 \mathrm{~kg} / \mathrm{h}$. Ebaid et al. (2004) developed the threshing chamber in a wheat thresher by removing the feeding auger to increase the feed rate and production rate. The machine was tested and evaluated under different operating conditions. The results showed that the purity efficiency of $99.30 \%$ and total grain losses of $0.16 \%$ were achieved at drum speed of $870 \mathrm{rpm}$, feed rate of $1200 \mathrm{~kg} / \mathrm{h}$, air speed suction of 32 $\mathrm{m} / \mathrm{s}$, blower speed of $6 \mathrm{~m} / \mathrm{s}$, and sieve tilt angle of $5^{\circ}$. El-Sahrigi $\boldsymbol{e t}$ al. 
(2004) designed and constructed a cleaning unit able to various types of medicinal and aromatic seeds and their associated foreign matter by making simple adjustments according to the type of seeds, its physical properties and associated impurities. They also, tested the performance of a cleaning unit under the following main factors: the frequency of the sieve unit, feed rate, air velocity and slop of the sieve unit. The maximum seed cleanliness and separation effectiveness were 99.01 and $89.75 \%$ respectively and obtained at frequency of $10.50 \mathrm{HZ}$, feed rate $300 \mathrm{~kg} / \mathrm{h}$, slope $13 \mathrm{deg}$. and air velocity 3.2 $\mathrm{m} / \mathrm{s}$. Zakaria (2006) developed the threshing drum in a local stationary thresher to suit separation of flax capsules. The machine was tested under feed rates of $8.57,12.86,17.14$ and $21.43 \mathrm{~kg} / \mathrm{min}$, and four drum speeds of $24.25,25.81,27.33$, and $28.85 \mathrm{~m} / \mathrm{s}$. The results showed that the optimum performance was at drum speed of $28.85 \mathrm{~m} / \mathrm{s}$, feed rate of $8.57 \mathrm{~kg} / \mathrm{min}$, drum fingers of 12 and separation time of 15 seconds where the threshing efficiency was $96.92 \%$. Zaky (2006) recommended that the optimum conditions to reduce the seed damage and total losses of black seed with acceptable level of cleaning efficiency were the drum speed ranged from 3.3 to $4.4 \mathrm{~m} / \mathrm{s}$, clearance ranged from $2.5-3 \mathrm{~mm}$ and air velocity of $2 \mathrm{~m} / \mathrm{s}$ to consumed energy of $25.12 \mathrm{~kW} . \mathrm{h} / \mathrm{Mg}$ and criterion cost of $752 \mathrm{~L} . \mathrm{E} / \mathrm{Mg}$. Afify et al. (2007) development of a local threshing machine suits for threshing black seed (Nigella sativa) The results showed that the minimum total seed losses of $2.63 \%$, stripping efficiency of $99.31 \%$, threshing efficiency of $98.74 \%$, cleaning efficiency of $95.88 \%$, required energy of $2.85 \mathrm{~kW} . \mathrm{h} / \mathrm{Mg}$ and criterion cost of $199.18 \mathrm{~L} . \mathrm{E} / \mathrm{Mg}$ were recorded under drum speed of $6.28 \mathrm{~m} / \mathrm{s}$, feed rate of $600 \mathrm{~kg} / \mathrm{h}$ and capsules moisture content of $13.63 \%$. Badr et al. (2009) developed and evaluated the performance of a threshing and cleaning machine suitable for medicinal and aromatic seeds plants (Fennel, caraway and coriander crops). They also, tested the performance of a threshing and cleaning machine under the following parameters: four different sieve speeds, four different sieve tilt angles, four different seed moisture contents and four different feed rates. The results showed that optimum performance was achieved under seed moisture contents of about (11.38, 7.50 and 10.26\%) for fennel, caraway and coriander respectively, a sieve speed and a sieve tilt angle of about $3.17 \mathrm{~Hz}$ 
and $2.0 \mathrm{deg}$. for the three crops respectively at air velocity of about 3.32 $\mathrm{m} / \mathrm{s}$.

Thus the objectives of this research are to:

- Manufacture a local threshing and cleaning machine to be suitable for medicinal and aromatic plants.

- Optimize some operating parameters drum speed, concave clearance and feed rate affecting the performance of the developed machine.

- Evaluate the developed machine from the economic point of view.

\section{MATERIALS AND METHODS}

Field experiments were carried out through successful agricultural season of 2012 at Department of Agricultural Engineering, Faculty of Agriculture, Zagazig University to evaluate the performance of a threshing and cleaning machine suitable for medicinal and aromatic seeds plants.

\section{The used crops:}

Three medicinal and aromatic crops were used in the study (anise, fennel and coriander). Some physical properties of the used crops were illustrated in Table (1), while some engineering properties were illustrated in Table (2).

\section{The manufactured threshing and cleaning machine:}

A threshing and cleaning machine, suitable for medicinal and aromatic crops, was manufactured from low cost, local material to overcome the problems of high power and high cost requirements under the use of the imported machines. The machine was manufactured specially for this work and constructed at a private workshop in Sharkia Governorate (Fig.1). The machine consists mainly of power source, transmission system, frame, threshing unit and cleaning unit.

\section{The power source:}

The machine was powered by an electric motor $3.68 \mathrm{~kW}(5.00 \mathrm{hp})$ at a rated speed of $3000 \mathrm{rpm}$. 
Table (1): Some physical properties of the used crops.

\begin{tabular}{|c|c|c|c|c|c|c|}
\hline \multirow{2}{*}{\multicolumn{2}{|c|}{ Physical properties }} & \multicolumn{5}{|c|}{ Crops } \\
\hline & & & nise & & inel & Coriander \\
\hline \multicolumn{2}{|l|}{ Length, mm } & \multicolumn{2}{|c|}{4.97} & \multicolumn{2}{|c|}{672} & 3.84 \\
\hline \multicolumn{2}{|l|}{ Width, mm } & \multicolumn{2}{|c|}{1.66} & \multicolumn{2}{|c|}{1.96} & 3.84 \\
\hline \multirow{2}{*}{\multicolumn{2}{|c|}{ Thickness, mm }} & \multicolumn{2}{|c|}{0.90} & \multicolumn{2}{|c|}{1.39} & 3.84 \\
\hline & & \multicolumn{2}{|c|}{6.17} & \multicolumn{2}{|c|}{9.94} & 11.17 \\
\hline \multicolumn{2}{|c|}{ Volume, $\mathbf{m m}^{3}$} & \multicolumn{2}{|c|}{4.99} & \multicolumn{2}{|c|}{9.58} & 29.63 \\
\hline \multicolumn{2}{|c|}{ Arithmetic diameter, mm } & \multicolumn{2}{|c|}{2.75} & \multicolumn{2}{|c|}{3.36} & 3.84 \\
\hline \multicolumn{2}{|c|}{ Geometric diameter, $\mathrm{mm}$} & \multicolumn{2}{|c|}{2.10} & \multicolumn{2}{|c|}{2.64} & 3.84 \\
\hline \multicolumn{2}{|c|}{ Frontal area, $\mathbf{m m}^{2}$} & \multicolumn{2}{|c|}{6.72} & \multicolumn{2}{|c|}{10.34} & 11.58 \\
\hline \multicolumn{2}{|c|}{ Transverse area, $\mathbf{m m}^{2}$} & \multicolumn{2}{|c|}{6.20} & \multicolumn{2}{|c|}{8.84} & 11.58 \\
\hline \multicolumn{2}{|c|}{ Percentage of sphericity, \% } & \multicolumn{2}{|c|}{50.60} & \multicolumn{2}{|c|}{39.22} & 100 \\
\hline \multicolumn{7}{|c|}{ Table (2): Some engineering properties of the used crops. } \\
\hline \multirow{3}{*}{ Crops } & \multicolumn{6}{|c|}{ Engineering properties } \\
\hline & \multicolumn{3}{|c|}{ Aerodynamic properties } & & $\begin{array}{l}\text { Mech } \\
\text { prop }\end{array}$ & $\begin{array}{l}\text { nanical } \\
\text { perties }\end{array}$ \\
\hline & $\begin{array}{c}\text { Critical } \\
\text { velocity of } \\
\text { seeds, } \mathbf{m} / \mathbf{s}\end{array}$ & $\begin{array}{c}\text { Impurities } \\
\text { critical } \\
\text { velocity, } \mathbf{m} / \mathbf{s}\end{array}$ & $\begin{array}{l}\text { Dyı } \\
\text { he: }\end{array}$ & & $\begin{array}{l}\text { Repose } \\
\text { angle, } \\
\text { deg. }\end{array}$ & $\begin{array}{c}\text { Friction } \\
\text { angle, } \\
\text { deg. }\end{array}$ \\
\hline Anise & $3.80-4.10$ & $1.80-2.00$ & 9.0 & 10 & 28 & 30 \\
\hline Fennel & $4.10-4.32$ & $2.10-2.33$ & 10.1 & 1.21 & 28 & 30 \\
\hline Coriander & $4.42-4.62$ & $2.44-2.62$ & 11.74 & 2.83 & 24 & 25 \\
\hline
\end{tabular}

The power source:

The machine was powered by an electric motor $3.68 \mathrm{~kW}(5.00 \mathrm{hp})$ at a rated speed of $3000 \mathrm{rpm}$.

The transmission system:

The machine is operated by means of machine pulley (170 $\mathrm{mm}$ diameter) and belt powered from the electric motor pulley ( $90 \mathrm{~mm}$ diameter). The power is transmitted from the machine pulley to the other moving parts by means of pulleys and belts with different speed ratios.

The frame:

The frame is made of rectangular iron sheet steel. It includes elements to fix the motor, the transmission system, the threshing and cleaning units. It was carried by four ground wheels of $300 \mathrm{~mm}$ diameter.

\section{The threshing unit:}

The threshing drum is of a spiked type, threshing drum length is $700 \mathrm{~mm}$, threshing drum diameter is $200 \mathrm{~mm}$, number of spikes rows is 6 , number of drum spikes is 48 , concave length is $700 \mathrm{~mm}$, concave cells shape is circle and concave cells diameter is $6 \mathrm{~mm}$ (fig.2). 

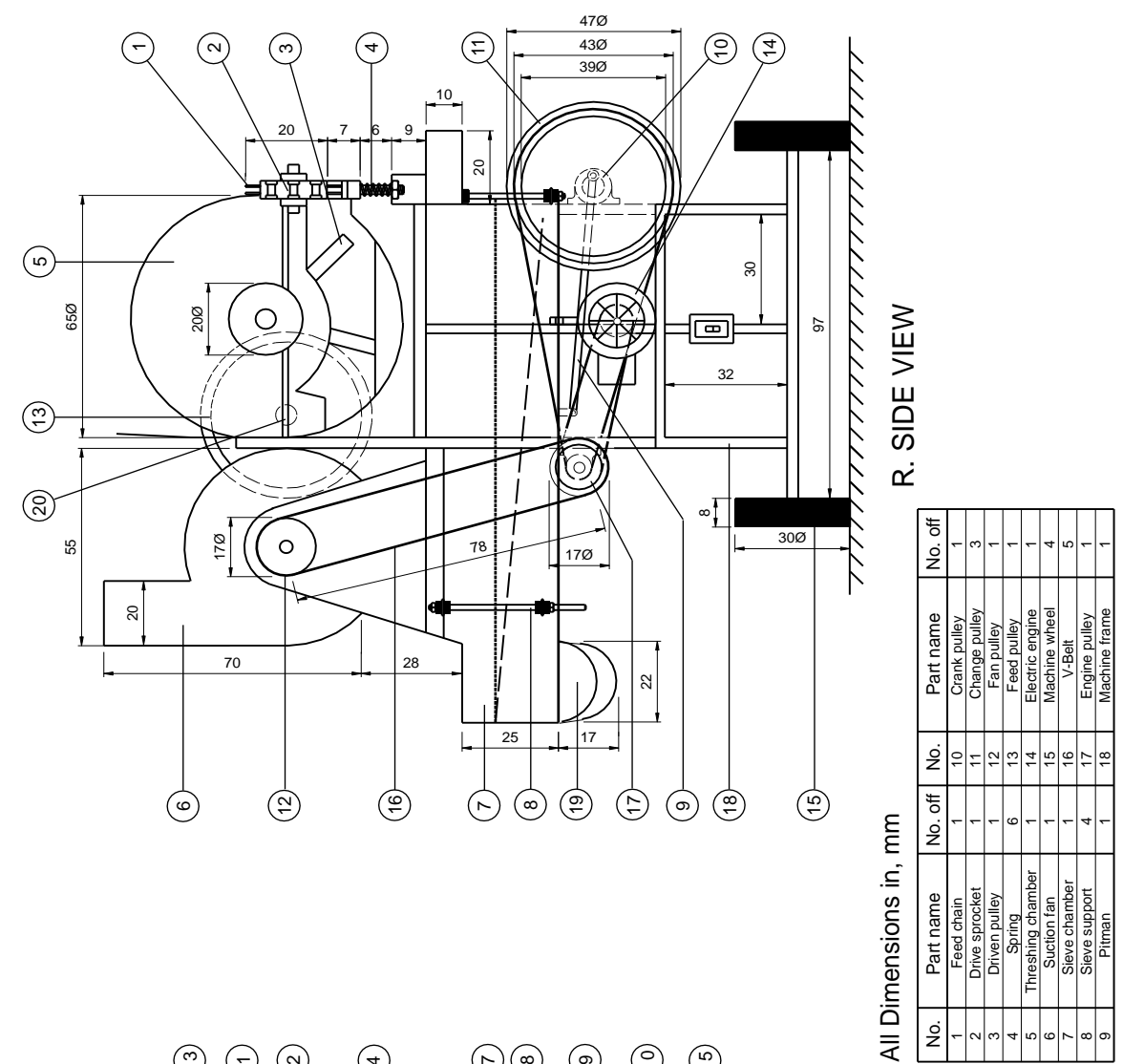

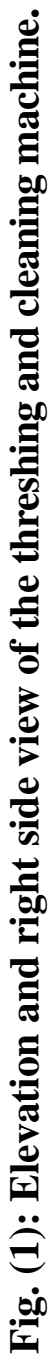

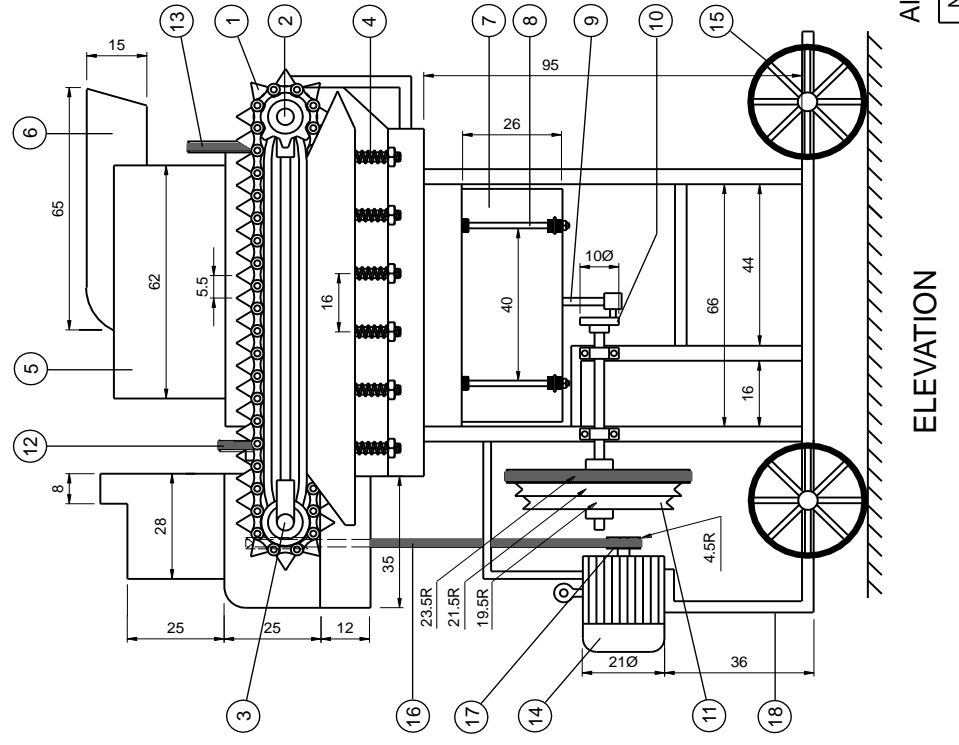




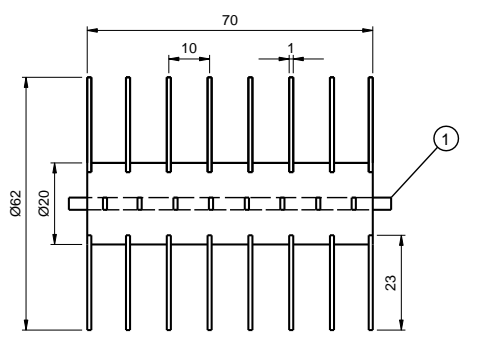

ELEVATION

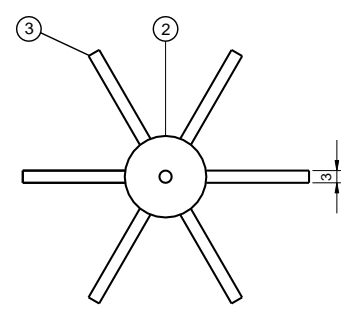

S.V.

\begin{tabular}{|c|c|c|}
\hline No. & Part name & No.off \\
\hline 1 & Drum shaft & 1 \\
\hline 2 & Threshing drum & 1 \\
\hline 3 & Beater & 45 \\
\hline
\end{tabular}

All dimensions in, $\mathrm{cm}$

Fig. (2): The threshing drum and its chamber.

\section{The cleaning system:}

The cleaning system consists of a suction fan, two sieves (upper and lower) and inclination pan.

\section{The main dimensions of the machine were as follows:}

Overall length $1750 \mathrm{~mm}$, overall width $1650 \mathrm{~mm}$, overall height 2000 $\mathrm{mm}$, and total weight $220 \mathrm{~kg}$.

\section{Preliminary experiments:}

Preliminary experiments were carried out to develop the threshing machine to be suitable for threshing and cleaning medicinal and aromatic crops. Most of modifications were conducted in both threshing and cleaning units. After each modification, the machine was operated and performance indicators were recorded until optimum modification was obtained.

The performance of the machine was experimentally measured under the following parameters:

- Four different drum speeds (350, 400, 450, and $500 \mathrm{rpm})$.

- Four different concave clearances $(8,9,10$, and $11 \mathrm{~mm})$.

- Four different feed rates: $(1.00,1.10,1.25$, and $1.45 \mathrm{Mg} / \mathrm{h}$ for anise crop), (1.05, 1.20, 1.35, and $1.55 \mathrm{Mg} / \mathrm{h}$ for fennel crop) and (1.10, 1.25, 1.50 , and $1.70 \mathrm{Mg} / \mathrm{h}$ for coriander crop). 
All experiments were carried out at constant sieve tilt angle of 2.0 degree, sieve speed of about 3.17 and air velocity of about $3.32 \mathrm{~m} / \mathrm{s}$. Seed moisture contents of $11.65 \%$ for anise, $12.10 \%$ for fennel and $11.20 \%$ for coriander were also kept constant during the experiments.

\section{Measurements and determinations:}

Evaluation of the performance of the developed machine was based on the following indicators:

\section{Threshing losses:}

Threshing losses was obtained by collecting both damaged and unthreshed seeds. The percentage of threshing losses was calculated by using the following equation:

$$
\text { Threshinglosses }(\%)=\frac{\mathrm{Ds}+\mathrm{U}_{\mathrm{n}} \cdot \mathrm{S}}{\mathrm{Ts}} \times 100
$$

Where: Ds: mass of damaged seeds per unit time, $\mathrm{kg}$

$\mathrm{U}_{\mathrm{n}} . \mathrm{S}$ : mass of un-threshed seeds per unit time, $\mathrm{kg}$

Ts: total sample mass, $\mathrm{kg}$

Damaged seeds percentage was calculated as follows:

$$
\text { Damaged seeds }(\%)=\frac{\mathrm{Ds}}{\mathrm{Ts}} \times 100
$$

Un-threshed seeds percentage was calculated as follows:

$$
\text { unthreshed seeds }(\%)=\frac{\mathrm{U}_{\mathrm{n}} \cdot \mathrm{S}}{\mathrm{Ts}} \times 100
$$

\section{Cleaning losses:}

Cleaning losses was obtained by collecting both fan losses and sieve losses. The percentage of cleaning losses was calculated by using the following equation:

$$
\text { Cleaning losses }(\%)=\frac{\mathrm{F}_{\mathrm{L}}+\mathrm{S}_{\mathrm{L}}}{\mathrm{Ts}} \times 100
$$

Where: $F_{L}$ : mass of fan losses per unit time, $\mathrm{kg}$

$\mathrm{S}_{\mathrm{L}}$ : mass of sieve losses per unit time, $\mathrm{kg}$

\section{Total losses:}

A total loss includes both threshing losses and cleaning losses. The percentage of total losses was calculated by using the following equation:

Totallosses $(\%)=$ Threshinglosses + Cleaninglosses 


\section{Overall machine efficiency:}

Overall machine efficiency was calculated by using the following equation:

$$
\text { Overallmachineefficiency }(\%)=\frac{\mathrm{C}_{\text {out }}}{\mathrm{Th}_{\text {in }}} \times 100
$$

Where: $\mathrm{C}_{\text {out }}=$ outputseeds from cleaning unit, $\mathrm{kg}$

$\mathrm{Th}_{\mathrm{in}}=$ total sample mass, $\mathrm{kg}$

\section{Machine productivity:}

Machine productivity was determined by the following equation:

$$
\mathrm{Mp}=\frac{\mathrm{Ms}}{\mathrm{t}}, \mathrm{kg} / \mathrm{h}
$$

Where: $\mathrm{Mp}=$ machine productivity, $\mathrm{kg} / \mathrm{h}$

Ws $=$ mass of sample, $\mathrm{kg}$

$\mathrm{t}=$ the time consumed in the threshing and cleaning operation, $\mathrm{h}$

\section{Required power:}

The following formula was used to estimate the required power.

$$
\mathrm{P}=\sqrt{3} \times \cos \varphi \times \mathrm{I} \times \mathrm{V}
$$

Where: $\mathrm{P}=$ power required, $\mathrm{kW}, \quad \mathrm{I}=$ current intensity, Ampere

$$
\mathrm{V}=\text { Voltage },(380 \mathrm{v}) \quad, \cos \varphi=0.7
$$

\section{Specific energy:}

Specific energy for the threshing and cleaning operation can be calculated as follows:

$$
\text { Specific energy }=\frac{\text { Motorpower }}{\text { Machineproductivity }}, \mathrm{kW} \cdot \mathrm{h} / \mathrm{kg}
$$

\section{Criterion cost:}

The criterion cost required for the threshing and cleaning operation was estimated using the following equation (Awady, 1982):

Criterion cost $=$ operating cost + seed losses cost, L.E./Mg

Where:

$$
\text { Operatingcost }=\frac{\text { Machinecost }}{\text { Machineproductivity }}, \text { L.E. } / \mathrm{Mg}
$$

The machine cost was determined by using the following equation (Awady, 1982): 


$$
\mathrm{C}=\frac{\mathrm{p}}{\mathrm{h}}\left(\frac{1}{\mathrm{a}}+\frac{\mathrm{i}}{2}+\mathrm{t}+\mathrm{r}\right)+(\mathrm{W} . \mathrm{e})+\frac{\mathrm{m}}{144}
$$

Where:

$$
\begin{array}{ll}
\mathrm{C}=\text { machine cost, L.E./h } & \mathrm{p}=\text { price of machine, } \mathrm{L} . \mathrm{E} . \\
\mathrm{h}=\text { yearly working hours, h/year } & \mathrm{a}=\text { life expectancy of the machine, } \\
\mathrm{h} & \mathrm{t}=\text { taxes, over heads ratio } \\
\mathrm{i}=\text { interest rate/year } & \mathrm{W}=\text { power of motor in } \mathrm{kW} \\
\mathrm{r}=\text { repairs and maintenance ratio } & \mathrm{m}=\text { the monthly average wage, } \\
\mathrm{e}=\text { hourly cost/kW.h } & \\
\begin{array}{l}
\text { L.E. } \\
\text { 144 = reasonable estimation of monthly working hours. }
\end{array}
\end{array}
$$

\section{RESULTS AND DISCUSSION}

The obtained results will be discussed under the following items:

\section{1- Influence of drum speed on threshing losses at different feed rates:}

Representative threshing losses values versus drum speed are given in Fig. 3. Considering anise crop, obtained results show that increasing drum speed from 350 to $450 \mathrm{rpm}$ measured at different feed rates of about $1.00,1.10,1.25$ and $1.45 \mathrm{Mg} / \mathrm{h}$, decreased threshing losses from 2.42 to 2.16 , from 2.34 to 2.09 , from 2.30 to 2.00 and from 2.37 to $2.12 \%$. Any further increase in drum speed more than 450 up to $500 \mathrm{rpm}$ measured at the same previous feed rates increased threshing losses from 2.16 to 2.35 , from 2.09 to 2.24 , from 2.00 to 2.15 and from 2.12 to $2.29 \%$, respectively at constant concave clearance of $9 \mathrm{~mm}$.

As to fennel crop, results show that increasing drum speed from 350 to $450 \mathrm{rpm}$ measured at different feed rates of about 1.05, 1.20, 1.35 and $1.55 \mathrm{Mg} / \mathrm{h}$, decreased threshing losses from 2.32 to 2.00 , from 2.22 to 1.90 , from 2.13 to 1.81 and from 2.28 to $1.94 \%$, further increase in drum speed more than 450 up to $500 \mathrm{rpm}$ measured at the same previous feed rates increased threshing losses from 2.00 to 2.20 , from 1.90 to 2.09 , from 1.81 to 2.00 and from 1.94 to $2.14 \%$, respectively at constant concave clearance of $9 \mathrm{~mm}$.

Concerning coriander crop, obtained data show that increasing drum speed from 350 to $400 \mathrm{rpm}$ measured at different feed rates of about 1.10, $1.25,1.50$ and $1.70 \mathrm{Mg} / \mathrm{h}$, decreased threshing losses from 2.05 to 1.90, 
from 1.94 to 1.80 , from 1.84 to 1.71 and from 1.98 to $1.83 \%$, the increase in drum speed more than 400 up to $500 \mathrm{rpm}$ measured at the same previous feed rates increased threshing losses from 1.90 to 2.21 , from 1.80 to 2.10 , from 1.71 to 2.00 and from 1.83 to $2.14 \%$, respectively at constant concave clearance of $10 \mathrm{~mm}$.

As shown in Fig. 3, the increase in seed damage by increasing drum speed is due to the high impacting force applied to the plants by the drum fingers. While the decrease in un-threshed seeds by increasing drum speed is attributed to the high stripping and impacting forces applied to the plants, that tended to improve threshing operation and decreased unthreshed seeds. On the other hand, increasing feed rate, increased unthreshed seeds due the excessive plants in the threshing unit, consequently the material leaves the device without well threshing that tends to increase un-threshed seeds. So, total losses including both seed damage and un-threshed seeds are essential to establish optimum working conditions (Fig. 3).

\section{2- Influence of concave clearance on threshing losses at different feed rates:}

Threshing losses is more sensitive to concave clearance for the three crops with different feed rates Fig. 4. Considering anise crop, obtained results show that increasing concave clearance from 8 to $9 \mathrm{~mm}$ measured at different feed rates of about $1.00,1.10,1.25$ and $1.45 \mathrm{Mg} / \mathrm{h}$, decreased threshing losses from 2.26 to 2.16 , from 2.17 to 2.09 , from 2.08 to 2.00 and from 2.20 to $2.12 \%$, further increase in concave clearance more than 9 up to $11 \mathrm{~mm}$ measured at the same previous feed rates increased threshing losses from 2.16 to 2.35 , from 2.09 to 2.25 , from 2.00 to 2.18 and from 2.12 to $2.30 \%$, respectively at constant drum speed of $450 \mathrm{rpm}$. Relating to fennel crop, results show that increasing concave clearance from 8 to $9 \mathrm{~mm}$ measured at different feed rates of about 1.05, 1.20, 1.35 and $1.55 \mathrm{Mg} / \mathrm{h}$, decreased threshing losses from 2.10 to 2.00 , from 2.00 to 1.90 , from 1.91 to 1.81 and from 2.03 to $1.94 \%$, the increase in concave clearance more than 9 up to $11 \mathrm{~mm}$ measured at the same previous feed rates increased threshing seed losses from 2.00 to 2.20, from 1.90 to 2.10 , from 1.81 to 2.02 and from 1.94 to $2.13 \%$, respectively at constant drum speed of $450 \mathrm{rpm}$. 

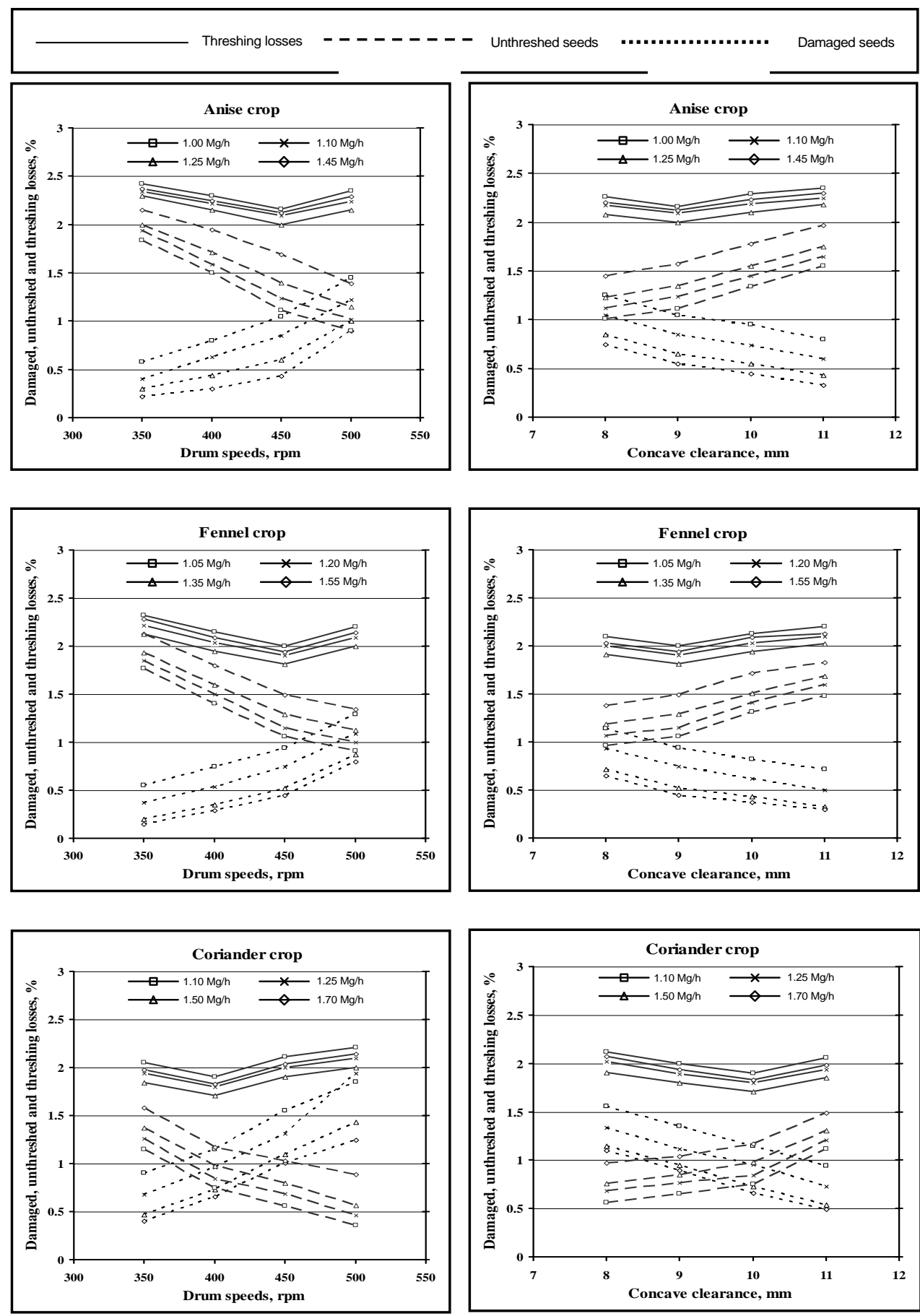

Fig. 3. Effect of drum speed on threshing losses at different feed rates for anise, fennel and coriander crops.

Fig. 4. Effect of concave clearance on threshing losses at different feed rates for anise, fennel and coriander crops. 
As to coriander crop, obtained data show that increasing concave clearance from 8 to $10 \mathrm{~mm}$ measured at different feed rates of about 1.10, $1.25,1.50$ and $1.70 \mathrm{Mg} / \mathrm{h}$, decreased threshing losses from 2.12 to 1.90 , from 2.02 to 1.80 , from 1.91 to 1.71 and from 2.07 to $1.83 \%$, any further increase in concave clearance more than 10 up to $11 \mathrm{~mm}$ measured at the same previous feed rates increased threshing losses from 1.90 to 2.06, from 1.80 to 1.94 , from 1.71 to 1.85 and from 1.83 to $1.98 \%$, respectively at constant drum speed of $400 \mathrm{rpm}$.

The decrease in seed damage by increasing concave clearance is due to the increase of threshed material thickness on the concave surface. While the increase in un-threshed seeds by increasing concave clearance is attributed to the low stripping and impacting forces applied to the medicinal and aromatic plants.

\section{3- Influence of drum speed on machine productivity and overall machine efficiency at different feed rates:}

Representative values of both machine productivity and overall machine efficiency versus drum speed at different feed rates are given in Fig. 5. Concerning anise crop, results show that increasing drum speed from 350 to $500 \mathrm{rpm}$ measured at different feed rates of about 1.00, 1.10, 1.25 and $1.45 \mathrm{Mg} / \mathrm{h}$, increased machine productivity from 360 to 404 , from 381 to 413 , from 392 to 422 and from 400 to $430 \mathrm{~kg} / \mathrm{h}$. The same results also show that increasing drum speed from 350 to $450 \mathrm{rpm}$ measured at the same previous feed rates increased overall machine efficiency from 96.58 to 96.84 , from 96.66 to 96.91 , from 96.70 to 97.00 and from 96.63 to $96.88 \%$. Further increase in drum speed more than 450 up to $500 \mathrm{rpm}$ measured at the same feed rates decreased overall machine efficiency from 96.84 to 96.65 , from 96.91 to 96.76 , from 97.00 to 96.85 and from 96.88 to $96.71 \%$, respectively at constant concave clearance of $9 \mathrm{~mm}$.

Relating to fennel crop, results show that increasing drum speed from 350 to $500 \mathrm{rpm}$ measured at different feed rates of about 1.05, 1.20, 1.35 and $1.55 \mathrm{Mg} / \mathrm{h}$, increased machine productivity from 416 to 470 , from 430 to 481 , from 443 to 490 and from 450 to $499 \mathrm{~kg} / \mathrm{h}$. While obtained results also show that increasing drum speed from 350 to $450 \mathrm{rpm}$ measured at the same previous feed rates increased overall machine efficiency from 96.68 to 97.00 , from 96.78 to 97.10 , from 96.87 to 97.19 and from 96.72 to $97.06 \%$. Any further increase in drum speed more than 
450 to $500 \mathrm{rpm}$ measured at the same feed rates decreased overall machine efficiency from 97.00 to 96.80 , from 97.10 to 96.91 , from 97.19 to 97.00 and from 97.06 to $96.86 \%$, respectively at constant concave clearance of $9 \mathrm{~mm}$.

As to coriander crop, obtained data show that increasing drum speed from 350 to $500 \mathrm{rpm}$ measured at different feed rates of about 1.10, 1.25, 1.50 and $1.70 \mathrm{Mg} / \mathrm{h}$, increased machine productivity from 325 to 380 , from 335 to 390 , from 344 to 400 and from 355 to $409 \mathrm{~kg} / \mathrm{h}$. While obtained results also show that increasing drum speed from 350 to 400 rpm measured at the same previous feed rates increased overall machine efficiency from 96.95 to 97.10 , from 97.06 to 97.20 , from 97.16 to 97.29 and from 97.02 to $97.17 \%$. Further increase in drum speed more than 400 up to $500 \mathrm{rpm}$ measured at the same feed rates decreased overall machine efficiency from 97.10 to 96.79 , from 97.20 to 96.90 , from 97.29 to 97.00 and from 97.17 to $96.86 \%$, respectively at constant concave clearance of The machine productivity increased by increasing drum speed because of the increase of seeds flow through the concave openings at the same time unit.

\section{4- Influence of concave clearance on machine productivity and overall machine efficiency at different feed rates:}

Representative values of both machine productivity and overall machine efficiency versus concave clearance at different feed rates are given in Fig. 6. Regarding anise crop, results show that increasing concave clearance from 8 to $11 \mathrm{~mm}$ measured at different feed rates of about 1.00, 1.10, 1.25 and $1.45 \mathrm{Mg} / \mathrm{h}$, increased machine productivity from 380 to 410 , from 388 to 420 , from 396 to 429 and from 402 to $440 \mathrm{~kg} / \mathrm{h}$. While the same results show that increasing concave clearance from 8 to $9 \mathrm{~mm}$ measured at the same previous feed rates increased overall machine efficiency from 96.74 to 96.84 , from 96.83 to 96.91 , from 96.92 to 97.00 and from 96.80 to $96.88 \%$, The further increase in concave clearance more than 9 up to $11 \mathrm{~mm}$ measured at the same feed rates decreased overall machine efficiency from 96.84 to 96.65 , from 96.91 to 96.75 , from 97.00 to 96.82 and from 96.88 to $96.70 \%$, respectively at constant concave clearance of $450 \mathrm{rpm}$.

$10 \mathrm{~mm}$. 

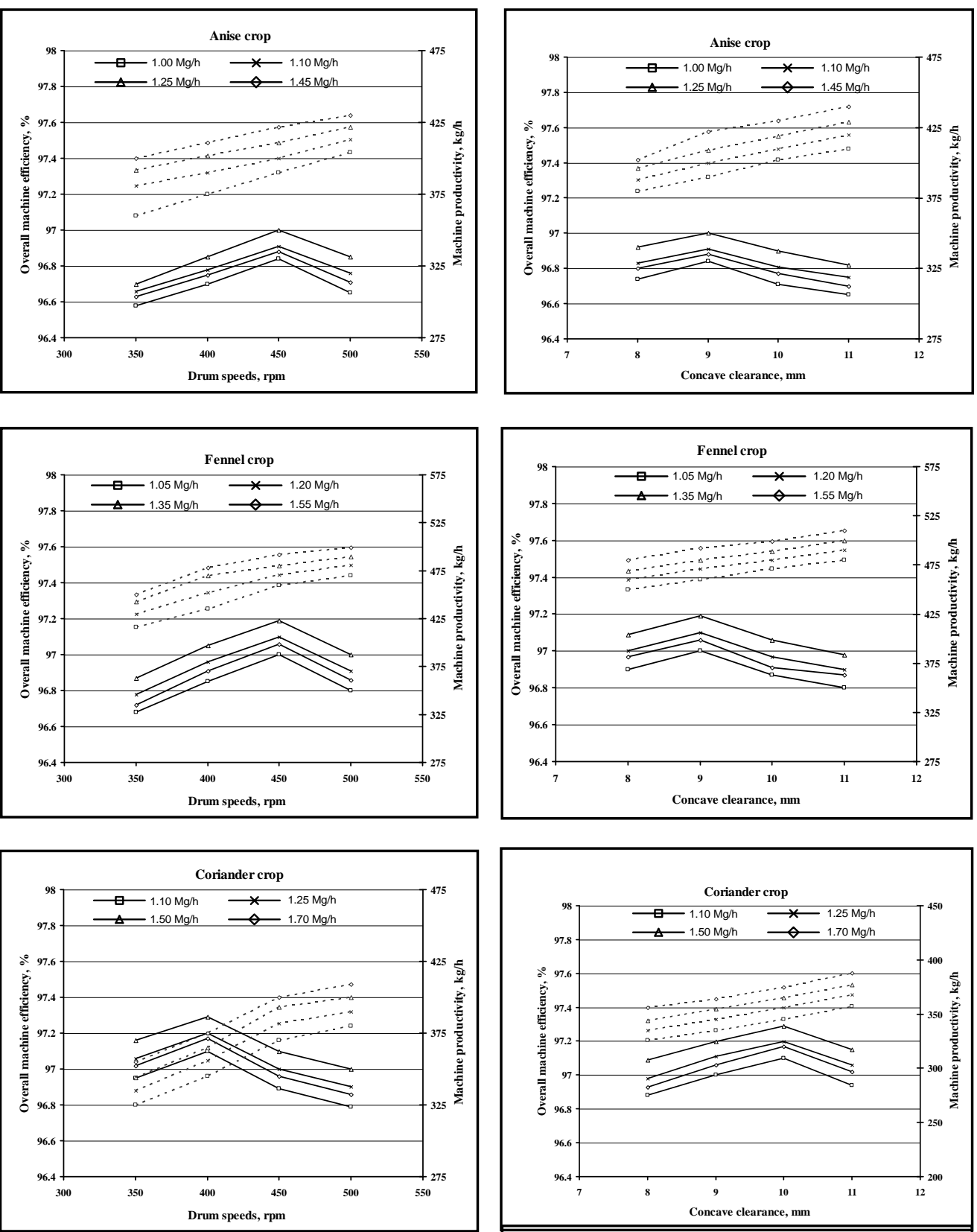

Fig. 5. Effect of drum speed on machine productivity and overall machine efficiency at different feed rates for anise, fennel and coriander crops.

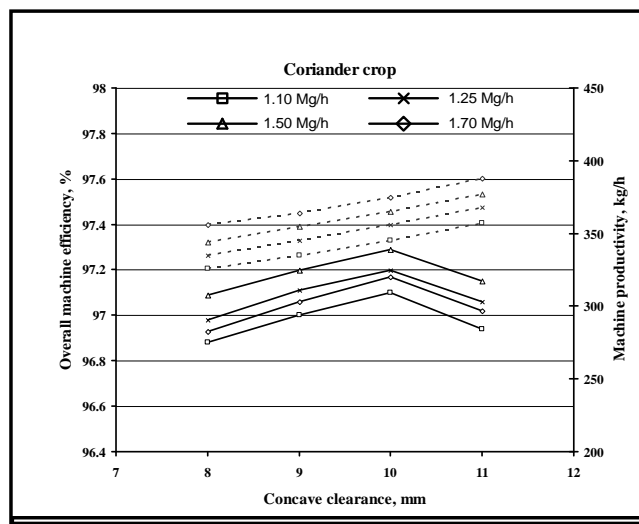

Fig. 6. Effect of concave clearance on machine productivity and overall machine efficiency at different feed rates for anise, fennel and coriander crops. 
Relating to fennel crop, results show that increasing concave clearance from 8 to $11 \mathrm{~mm}$ measured at different feed rates of about 1.05, 1.20, 1.35 and $1.55 \mathrm{Mg} / \mathrm{h}$, increased machine productivity from 450 to 480 , from 460 to 490 , from 469 to 500 and from 480 to $510 \mathrm{~kg} / \mathrm{h}$. While obtained results also show that increasing concave clearance from 8 to 9 $\mathrm{mm}$ measured at the same previous feed rates increased overall machine efficiency from 96.90 to 97.00 , from 97.00 to 97.10 , from 97.09 to 97.19 and from 96.97 to $97.06 \%$, The further increase in concave clearance more than 9 up to $11 \mathrm{~mm}$ measured at the same feed rates decreased overall machine efficiency from 97.00 to 96.80 , from 97.10 to 96.90 , from 97.19 to 96.98 and from 97.06 to $96.87 \%$, respectively at constant concave clearance of $450 \mathrm{rpm}$.

With regard to coriander crop, obtained data show that increasing concave clearance from 8 to $11 \mathrm{~mm}$ measured at different feed rates of about $1.10,1.25,1.50$ and $1.70 \mathrm{Mg} / \mathrm{h}$, increased machine productivity from 326 to 357 , from 335 to 368 , from 344 to 377 and from 356 to 388 $\mathrm{kg} / \mathrm{h}$. While obtained results also show that increasing concave clearance from 8 up to $10 \mathrm{~mm}$ measured at the same previous feed rates increased overall machine efficiency from 96.88 to 97.10 , from 96.98 to 97.20 , from 97.09 to 97.29 and from 96.93 to $97.17 \%$, The further increase in drum speed more than 10 up to $11 \mathrm{~mm}$ measured at the same feed rates decreased overall machine efficiency from 97.10 to 96.94 , from 97.20 to 97.06, from 97.29 to 97.15 and from 97.17 to $97.02 \%$, respectively at constant drum speed of $400 \mathrm{rpm}$. The machine productivity increased by increasing concave clearance because of the increase of seeds flow through the concave openings at the same time unit.

\section{5- Influence of drum speed on power and specific energy at different feed rates:}

Power and specific energy are too related to drum speed as shown in Fig. 7. Concerning anise crop, results show that increasing drum speed from 350 to $500 \mathrm{rpm}$ measured at different feed rates of about 1.00, 1.10, 1.25 and $1.45 \mathrm{Mg} / \mathrm{h}$, increased the required power from 1.51 to 2.10 , from 1.68 to 2.21 , from 1.80 to 2.33 and from 1.93 to $2.41 \mathrm{~kW}$. Also increased specific energy from 4.19 to 5.20 , from 4.41 to 5.35 , from 4.59 to 5.52 
and from 4.83 to $5.60 \mathrm{~kW} \cdot \mathrm{h} / \mathrm{Mg}$ respectively at constant concave clearance of $9 \mathrm{~mm}$.

Relating to fennel crop, results show that increasing drum speed from 350 to $500 \mathrm{rpm}$ measured at different feed rates of about 1.05, 1.20, 1.35 and $1.55 \mathrm{Mg} / \mathrm{h}$, increased the required power from 1.72 to 2.19 , from 1.88 to 2.30 , from 2.00 to 2.45 and from 2.10 to $2.60 \mathrm{~kW}$. Also increased specific energy from 4.13 to 4.66 , from 4.37 to 4.78 , from 4.51 to 5.00 and from 4.67 to $5.21 \mathrm{~kW} . \mathrm{h} / \mathrm{Mg}$ respectively, at constant concave clearance of $9 \mathrm{~mm}$.

As to coriander crop, obtained data show that increasing drum speed from 350 to $500 \mathrm{rpm}$ measured at different feed rates of about 1.10, 1.25, 1.50 and $1.70 \mathrm{Mg} / \mathrm{h}$, increased the required power from 2.15 to 2.75 , from 2.30 to 2.88 , from 2.40 to 3.00 and from 2.55 to $3.15 \mathrm{~kW}$. Also increased specific energy from 6.62 to 7.24 , from 6.87 to 7.38 , from 6.98 to 7.50 and from 7.18 to $7.70 \mathrm{~kW} . \mathrm{h} / \mathrm{Mg}$ respectively, at constant concave clearance of $10 \mathrm{~mm}$.

Power and specific energy increased by increasing drum speed mainly because the increase in drum speed is frequently accompanied by appreciable increase in electric consumption, that tends to increase power and energy.

\section{6- Influence of concave clearance on power and specific energy at different feed rates:}

Power and specific energy are greatly affected by the concave clearance as shown in Fig. 8.

Concerning anise crop, results show that increasing concave clearance from 8 to $11 \mathrm{~mm}$ measured at different feed rates of about 1.00, 1.10, 1.25 and $1.45 \mathrm{Mg} / \mathrm{h}$, decreased the required power from 2.12 to 1.76 , from 2.23 to 1.85 , from 2.33 to 1.96 and from 2.42 to $2.06 \mathrm{~kW}$. Also decreased specific energy from 5.58 to 4.29 , from 5.75 to 4.40 , from 5.88 to 4.57 and from 6.02 to $4.68 \mathrm{~kW} . \mathrm{h} / \mathrm{Mg}$ respectively at constant drum speed of $450 \mathrm{rpm}$. 

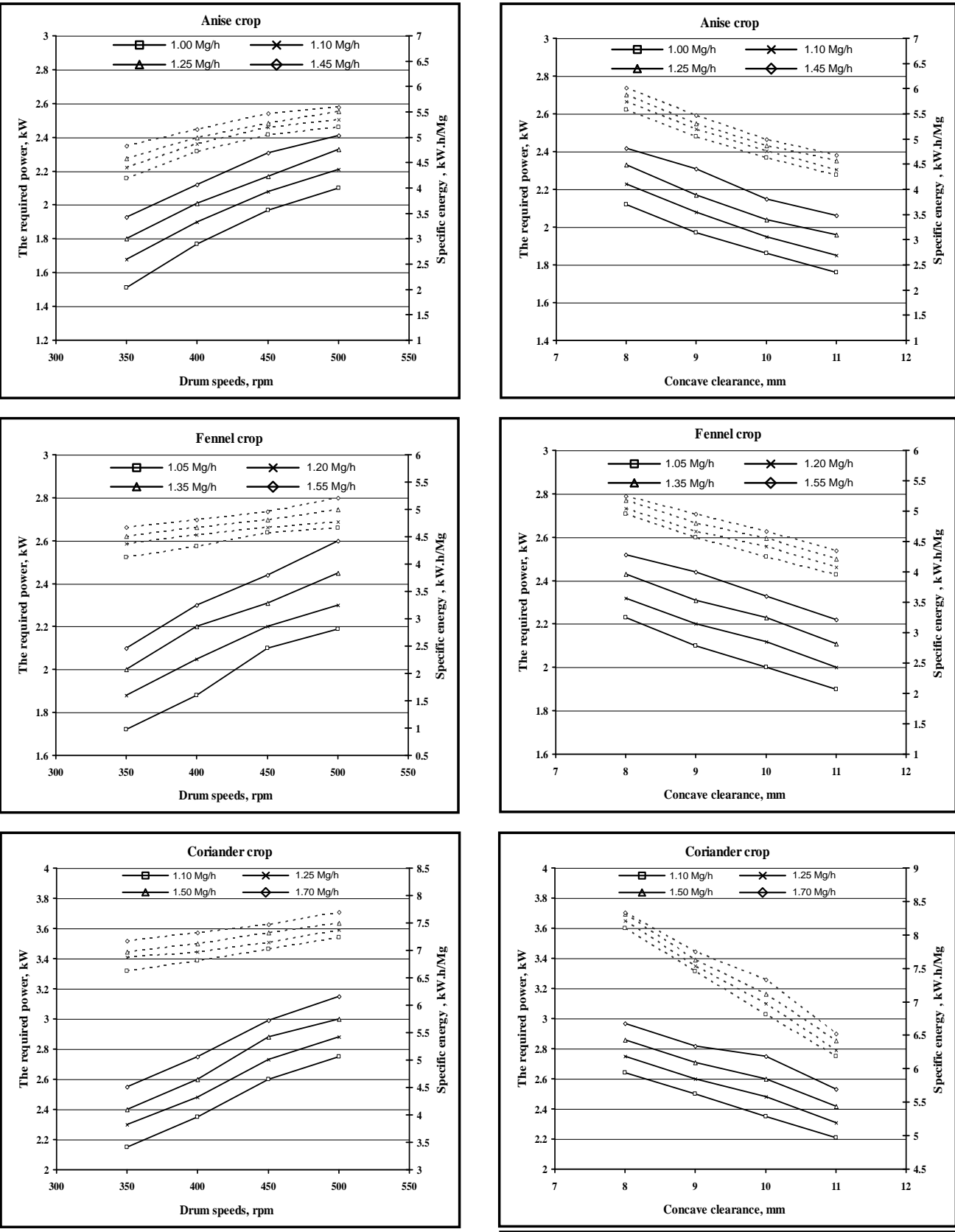

Fig. 7. Effect of drum speed on power and energy requirements at different feed rates for anise, fennel and coriander crops.

Fig. 8. Effect of concave clearance on power and energy requirements at different feed rates for anise, fennel and coriander crops. 
Relating to fennel crop, results show that increasing concave clearance 8 to $11 \mathrm{~mm}$ measured at different feed rates of about 1.05, 1.20, 1.35 and $1.55 \mathrm{Mg} / \mathrm{h}$, decreased the required power from 2.23 to 1.90 , from 2.32 to 2.00, from 2.43 to 2.11 and from 2.52 to $2.22 \mathrm{~kW}$. Also decreased specific energy from 4.96 to 3.96 , from 5.04 to 4.08 , from 5.18 to 4.22 and from 5.25 to $4.35 \mathrm{~kW} . \mathrm{h} / \mathrm{Mg}$ respectively, at constant drum speed of $450 \mathrm{rpm}$.

As to coriander crop, obtained data show that increasing concave clearance from 8 to $11 \mathrm{~mm}$ measured at different feed rates of about 1.10, $1.25,1.50$ and $1.70 \mathrm{Mg} / \mathrm{h}$, decreased the required power from 2.64 to 2.21, from 2.75 to 2.31 , from 2.86 to 2.42 and from 2.97 to $2.53 \mathrm{~kW}$. Also decreased specific energy from 8.10 to 6.19 , from 8.21 to 6.28 , from 8.31 to 6.42 and from 8.34 to $6.52 \mathrm{~kW} . \mathrm{h} / \mathrm{Mg}$ respectively, at constant drum speed of $400 \mathrm{rpm}$.

The decrease in both power and energy by increasing concave clearance is attributed to smoothly and the easy seeds flow on the concave surface that reduces power and energy.

\section{7- Influence of drum speed on operational and criterion costs at different feed rates:}

Drum speed is considered an important factor, which affects operational and criterion costs Fig. 9. As to anise crop, results show that increasing drum speed from 350 to $450 \mathrm{rpm}$ measured at different feed rates of about $1.00,1.10,1.25$ and $1.45 \mathrm{Mg} / \mathrm{h}$, decreased criterion cost from 226.56 to 209.28 , from 219.49 to 204.50 , from 216.02 to 198.66 and from 218.50 to 203.39 L.E/Mg respectively at constant concave clearance of $9 \mathrm{~mm}$. Any further increase in drum speed from 450 to 500 rpm, criterion cost will increase from 209.28 to 217.00 , from 204.50 to 212.01, from 198.66 to 204.89 and from 203.39 to 210.43 L.E./Mg under the same previous conditions. 

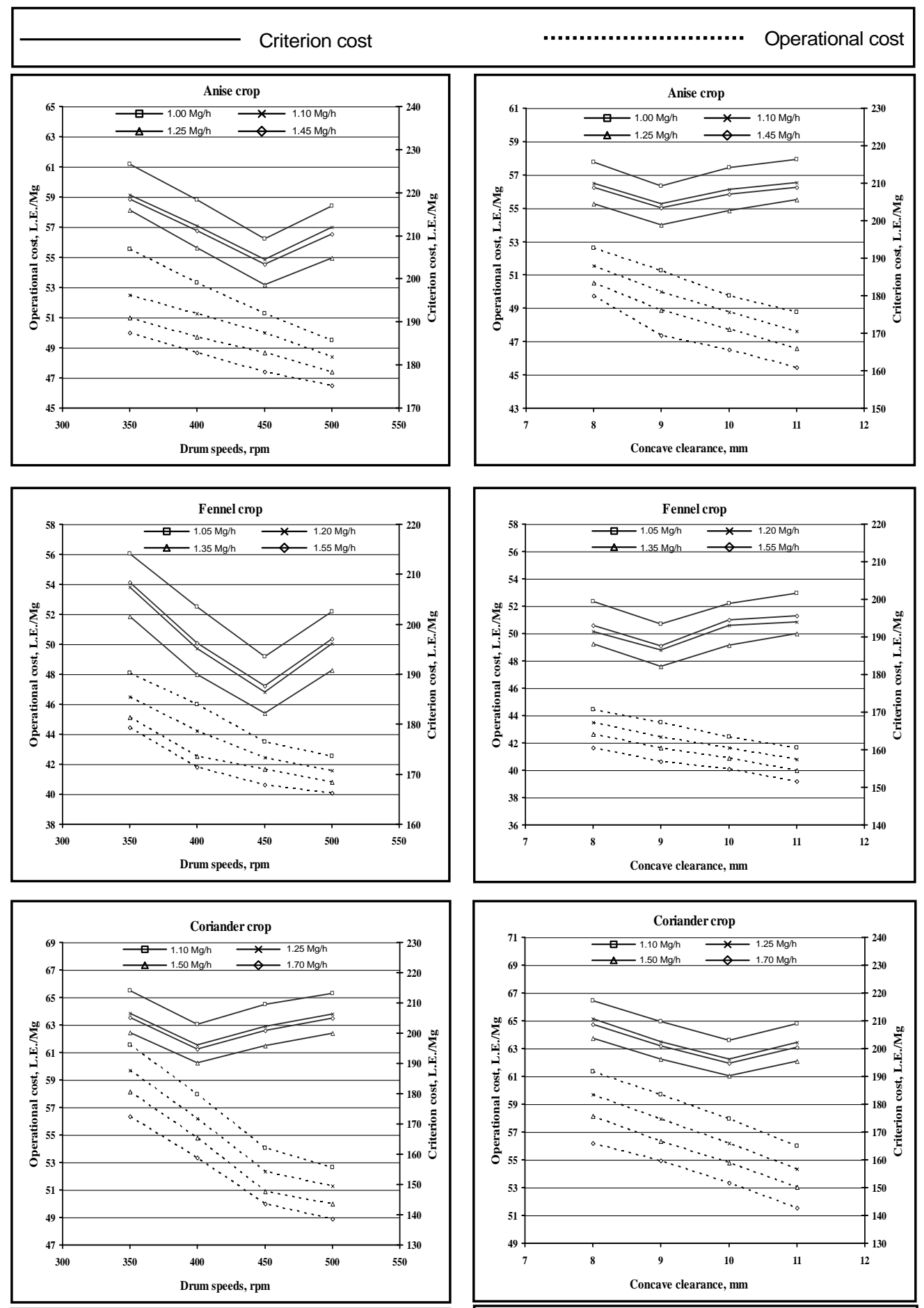

Fig. 9. Effect of drum speed on operational and criterion costs at different feed rates for anise, fennel and coriander crops.

Fig. 10. Effect of concave clearance on operational and criterion costs at different feed rates for anise, fennel and coriander crops.

Misr J. Ag. Eng., July 2012 
Relating to fennel crop, obtained data show that increasing drum speed from 350 to $450 \mathrm{rpm}$ measured at different feed rates of about 1.05, 1.20, 1.35 and $1.55 \mathrm{Mg} / \mathrm{h}$, decreased criterion cost from 214.08 to 193.48 , from 207.51 to 186.46 , from 201.65 to 182.17 and from 208.44 to 187.65 L.E./Mg respectively at constant concave clearance of $9 \mathrm{~mm}$. Any further increase in drum speed from 450 to $500 \mathrm{rpm}$, criterion cost will increase from 193.48 to 202.55 , from 186.46 to 196.08 , from 182.17 to 190.82 and from 187.65 to 197.08 L.E./Mg under the same previous conditions. Regarding coriander crop, results show that increasing drum speed from 350 to $400 \mathrm{rpm}$ measured at different feed rates of about 1.10, 1.25, 1.50 and $1.70 \mathrm{Mg} / \mathrm{h}$, decreased criterion cost from 214.04 to 202.97 , from 206.70 to 196.18 , from 200.14 to 190.29 and from 205.34 to 194.83 L.E./Mg respectively at constant concave clearance of $10 \mathrm{~mm}$. Any further increase in drum speed from 400 to $500 \mathrm{rpm}$, criterion cost will increase from 202.97 to 213.13 , from 196.18 to 206.28 , from 190.29 to 200.00 and from 194.83 to 204.90 L.E./Mg under the same previous conditions. Both higher and lower values of drum speed more or less than the optimum value tend to increase criterion cost due to the increase in total seed losses.

\section{8- Influence of concave clearance on operational and criterion costs at different feed rates:}

Operational and criterion costs are greatly affected by concave clearance. This relation can be remarked in Fig. 10. As to anise crop, results show that increasing concave clearance from 8 to $9 \mathrm{~mm}$ measured at different feed rates of about $1.00,1.10,1.25$ and $1.45 \mathrm{Mg} / \mathrm{h}$, decreased criterion cost from 215.63 to 209.28 , from 210.05 to 204.50 , from 204.51 to 198.90 and from 209.00 to 203.39 L.E/Mg respectively at constant drum speed of $450 \mathrm{rpm}$. Any further increase in concave clearance from 9 to 11 $\mathrm{mm}$, criterion cost will increase from 209.28 to 216.28 , from 204.50 to 210.12, from 198.90 to 205.62 and from 203.39 to 209.00 L.E./Mg under the same previous conditions.

Relating to fennel crop, obtained data show that increasing concave clearance from 8 to $9 \mathrm{~mm}$ measured at different feed rates of about 1.05, $1.20,1.35$ and $1.55 \mathrm{Mg} / \mathrm{h}$, decreased criterion cost from 199.44 to 193.48 , 
from 191.48 to 186.46 , from 188.14 to 182.17 and from 193.17 to 187.65 L.E./Mg respectively at constant drum speed of $450 \mathrm{rpm}$. Any further increase in concave clearance from 9 to $11 \mathrm{~mm}$, criterion cost will increase from 193.48 to 201.67 , from 186.46 to 194.00 , from 182.17 to 191.00 and from 187.65 to 195.72 L.E./Mg under the same previous conditions.

Regarding coriander crop, results show that increasing concave clearance from 8 to $10 \mathrm{~mm}$ measured at different feed rates of about 1.10, 1.25, 1.50 and $1.70 \mathrm{Mg} / \mathrm{h}$, decreased criterion cost from 217.35 to 202.97 , from 210.70 to 196.18 , from 203.64 to 190.29 and from 208.68 to 194.83 L.E./Mg respectively at constant drum speed of $400 \mathrm{rpm}$. Any further increase in concave clearance from 10 to $11 \mathrm{~mm}$, criterion cost will increase from 202.97 to 209.02 , from 196.18 to 201.35 , from 190.29 to 195.55 and from 194.83 to 200.55 L.E./Mg under the same previous conditions. Both higher and lower values of concave clearance more or less than the optimum value tend to increase criterion cost due to the increase in total seed losses.

\section{CONCLUSION}

The experimental results recommended the following:

- Operate the manufactured machine at a drum speed of about $450 \mathrm{rpm}$ for anise and fennel crops, and 400 rpm for coriander crop.

- Operate the manufactured machine at a concave clearance of about 9 $\mathrm{mm}$ for anise and fennel crops, and $10 \mathrm{~mm}$ for coriander crop.

- Adjust the feed rates at $1.25,1.35$ and $1.50 \mathrm{Mg} / \mathrm{h}$ for anise, fennel and coriander respectively.

\section{REFERRENCES}

Afify, M. K; M. M. A. El-Sharabasy and M. M. A. Ali (2007): development of a local threshing machine suits for threshing black seed (Nigella sativa). Misr J. Ag. Eng., 24 (4):699 - 724.

Awady, M. N; E. Y. Ghoniem, and A. I. Hashish (1982): Agriculture comparison between wheat combine harvesters under Egyptian conditions. Res. Bul. Ain-Shams Univ.:13p. 
Badawy, M. E. (2002): Modification and evaluation of paddy rice thresher to suit flax deseeding . Misr J. Ag. Eng., 19 (4): 881-900.

Badr M. M; M. A. Hassan, M. M. Morad and M. A. Arnaout (2009): Engineering parameters required for the design and development of cleaning machine for medicinal and aromatic seed crops. Ph.D. Thesis Agric. Eng. Dep., Fac. of Agric. Zagazig Univ.

Ebaid, M. T; A. A. Abd El-Rahman, G. G. Radwan and H. E. Osman (2004): Development of a thresher for wheat of beater type for maximum productivity. Misr J. Ag. Eng. , 21 (1):14 - 28.

El-Hadad, W. Z. (2000): A simplified design and performance study of threshing and winnowing machine suitable for small holdings. M. Sc. Thesis. Agric. Mech., Fac. Of Agric., Kafr El-Sheikh, Tanta Univ.

El-Nono, M. A. and A. H. A. Mohammed (2000): A study on power requirements for wheat threshing. Egypt. J. Agric. Res. 78(5): 21692176.

El-Sahrigi, A. F. M; S. F. Ahmed, M. A. Helmy, H. M. Sorour and S. S. Hanna (2004): Construction and development of a cleaning unit suitable for medicinal and aromatic seed crops. Misr J. Ag. Eng., 21(4): $53-66$.

Mamdouh A. H; S. I. Yousef and A. M. Badawy (2000): Performance evaluation of some sunflower thresher. Egyptian Journal of Agricultural Research, 78(2): 969 - 973.

Simonyan K. J. and K. C. Oni (2001): Performance evaluation of a motorized locust bean decorticator. Journal of Agricultural Technology 9(1): 55 - 65.

Zakaria, M. I. (2006): Modification of the thresher drum of stationary thresher to suit separating of flax crop. Misr J. Ag. Eng., 23(2): 324345 .

Zaky, W. M. (2006): Engineering studies on threshing of black seed (Nigella Sativa). M. Sc. Thesis. Agric. Eng. Dep., Fac. of Agric., Mansoura Univ. 


\section{الملخص العربـى

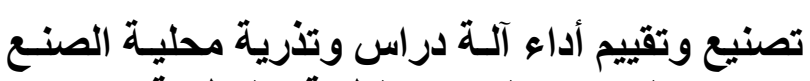 \\ لتناسب النباتات الطبية والعطرية

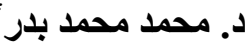

تم تتفيذ التجارب الحقلية بقسم الهندسة الزر اعية ـ كلية الزراعة ـ جامعة الزقازيق لتقييم أداء

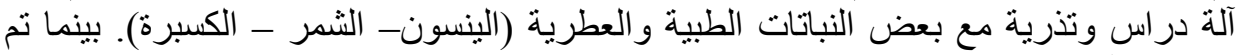

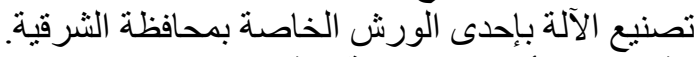

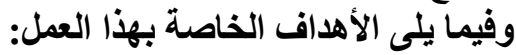
ا - تصنيع وتقييم أداء آلة دراس وتذافية ولذرية محلية الصنع تناسب بعض النباتات الطبية و العطرية. זـ ـ تحديد القيم التشغيلية المثلى لكل من سرعة درفيل الدراس والخلوص بين الدرفيل و الصدر ومعدلات التلقيم والتى تؤثر على الته أداء الآلة. ب- تقييم الآلة المطورة من الناحية الاقتصنادية.

ولدراسة أداء الآلة تم أخذ بعض الآلة المعاملات التالية فى الاعتبار : أربع سرعات مخت مختلفة لدرفيل

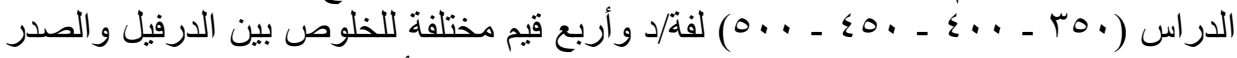

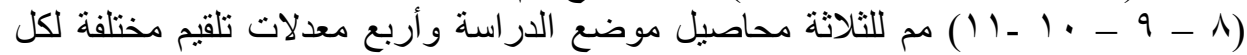

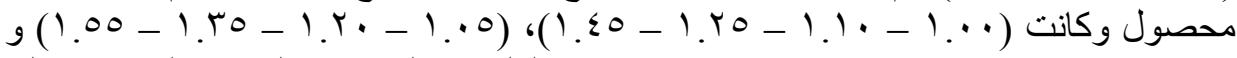

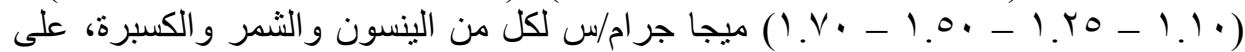

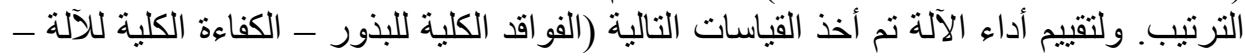

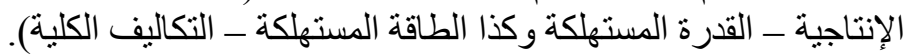

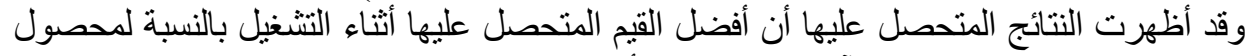

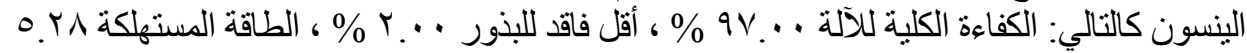

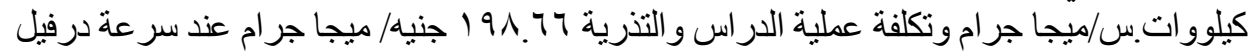

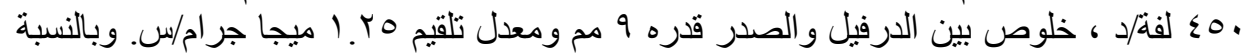

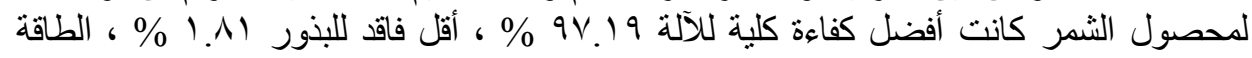

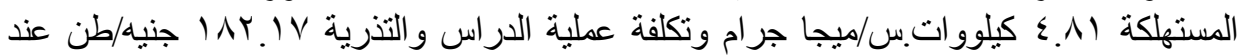

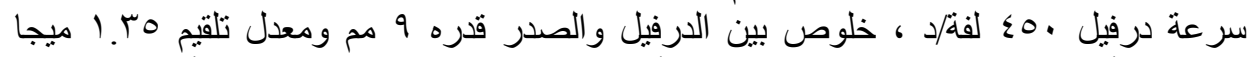

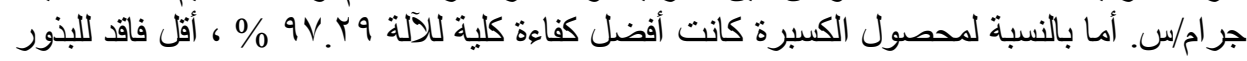

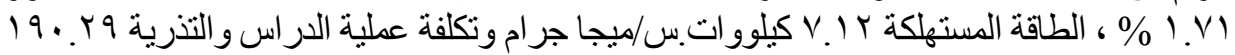

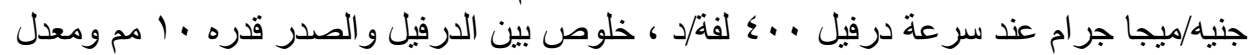

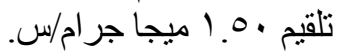

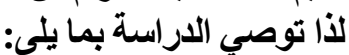

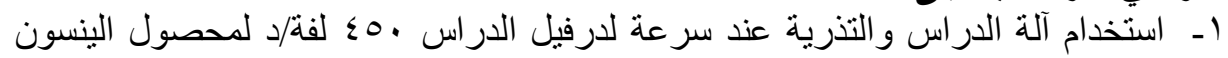

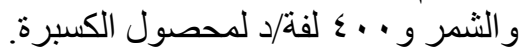

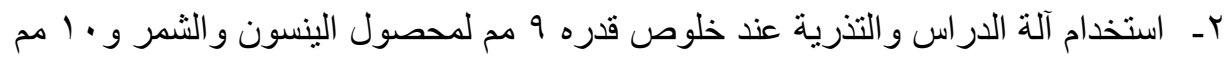
لمحصول الكسبرة.

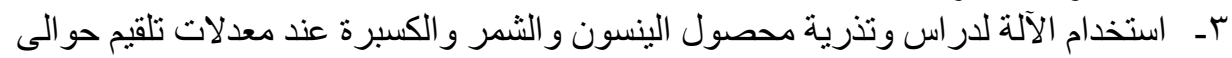

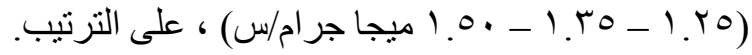
"مدرس - قسم الهندسة الزراعية ـ كلية الزراعة - جامعة الزقازيق - مصر. 